\title{
APLIKASI PEMBELIAN DAN PENJUALAN DI TOKO BANGUNAN REDHA DUMAI MENGGUNAKAN BAHASA PEMOGRAMAN VB 6.0
}

\author{
Wira M. Ghofur ${ }^{1}$, Masrizal ${ }^{2}$, Adi Arianto ${ }^{3}$ \\ ${ }^{1,2,3}$ Sekolah Tinggi Manajemen Informatika dan Komputer (STMIK) Dumai \\ Jl. Utama Karya Bukit Batrem Dumai Kode Pos 28811 \\ e-mail : gopur855@gmail.com
}

\begin{abstract}
ABSTRAK
Toko adalah sebuah tempat yang digunakan untuk terjadinya proses transaksi baik itu penjualan maupun pembelian, dimana permasalahannya yang dijadikan dasar dalam penulisan ini yaitu pada Toko Redha Dumai saat ini, pencatatan transaksi penjualan dan pembelian serta laporan-laporan masih menggunakan cara manual, cara ini masih membutuhkan waktu yang cukup lama, dan rentan kesalahan perhitungan, sehingga harus kerja berulang-ulang. Selain itu dalam proses pencarian data dan persediaan barang juga masih menggunakan cara manual. Maka dari itu dengan adanya aplikasi penjualan dan pembelian yang akan di rancang agar dapat mengatasi masalah-masalah dalam melakukan transaksi pembelian dan penjualan pada toko Redha Dumai, sehinga bertujuan untuk membuat semua transaksi tersimpan dengan aman dan tanpa harus takut hilangnya lapaoran setiap transaksi pada toko Redha Dumai.
\end{abstract}

Kata kunci : aplikasi, penjualan, pembelian, transaksi

\section{PENDAHULUAN}

Toko bangunan Redha Dumai merupakan salah satu usaha yang bergerak dibidang penjualan dan pembelian material bahan bangunan. Toko bangunan Redha Dumai berlokasi di Jl. Sultan Hasanuddin kota Dumai dan tempatnya terletak diantara dua restoran mahal di kota Dumai yaitu sebelah kiri Aroma Seafood dan disebelah kanannya Laguna Seafood. Toko bangunan Redha Dumai pertama kali di rintis oleh ibu Nardha pada tahun 1996 sampai sekarang. Toko bangunan Redha termasuk toko paling lama di kota Dumai, juga termasuk toko pertama di jalan Sultan Hasanuddin dan juga menjual barang dengan harga yang relatif murah dan pelayanannya juga ramah.

Pada Toko Redha Dumai saat ini, pencatatan transaksi penjualan dan pembelian serta laporan-laporan masih menggunakan cara manual, cara ini masih membutuhkan waktu yang cukup lama, dan rentan kesalahan perhitungan, sehingga harus kerja berulangulang. Selain itu dalam proses pencarian data dan persediaan barang juga masih menggunakan cara manual.Hal ini tentunya tidak diinginkan oleh toko ini. Bahkan toko ini pun dapat kehabisan produk tertentu dari waktu ke waktu ketika penjualan lebih besar dari apa yang mereka perkirakan. Hal ini dapat menyebabkan kerugian karena tidak ada persediaan yang tersedia untuk dijual ke konsumen. Dengan sistem pengendalian persediaan stock barang yang baik, toko dapat meminimalkan kekurangan persediaan barang. Sebagian besar toko berharap mereka tidak memiliki kekurangan persediaan stock barang dengan jumlah yang besar dan juga tidak harus terlalu banyak menimbun persediaan.

Tujuan dari penelitian ini adalah untuk membuat suatu aplikasi penjualan pada Toko bangunan Redha Dumai agar dalam proses penjualan dan pembelian yang di lakukan pada Toko Redha Dumai dapat lebih mudah dan dapat tercatat dengan baik.

\section{a. Toko}

toko adalah sebuah tempat tertutup yang di dalamnya terjadi kegiatan perdagangan dengan jenis benda atau barang yang khusus, misalnya toko buku, toko buah dan sebagainya.(Suprayitno, 2012) 
IN F ORM T IK A

Jurnal Informatika, Manajemen dan Komputer, Vol. 10 No. 1, MEI 2018

eISSN : 2580-3042

pISSN : 1979-0694

b. Aplikasi

aplikasi komputer merupakan suatu perangkat lunak komputer yang memiliki fungsi tertentu sesuai dengan tujuan yang diinginkan oleh si pembuat aplikasi (Programer).Aplikasi komputer biasanya diciptakan untuk mempermudah manusia dalam mengerjakan suatu tugas didalam sebuah komputer, seperti untuk mengolah data maupun untuk keperluan editing.Dijaman yang serba canggih ini peran Aplikasi komputer dalam kehidupan sehari-hari dapat kita jumpai dalam berbagai bidang, misal untuk keperluan bisnis, pendidikan maupun untuk hiburan.Dengan hadirnya beberapa aplikasi komputer tersebut semua orang bisa bekerja dengan mudah dan menghemat waktu. (Yunita, 2018)

\section{c. Aliran Sistem Informasi}

Aliran sistem informasimerupakan bagan yang menunjukan arus pekerjaan serta keseluruhan dari system. Bagan ini menjelaskan urutan dari prosedur-prosedur yang ada dalam sistem.(Ismael, 2017)

\section{d. Data Flow Diagram ( DFD )}

Data Flow Diagram (DFD) merupakan sebuah alat yang menggambarkan aliran data sampai sebuah sistem selesai, dan kerja atau proses dilakukan dalam sistem tersebut. Istilah dalam bahasa indonesianya adalah diagram aliran data.

Dalam DFD ini terdapat 4 komponen utama, yaitu :

1. External Agents

Agen eksternal mendefinisikan orang atau sebuah unit organisasi sistem lainnya, atau organisasi yang berada diluar sistem proyek tapi dapat mempengaruhi kerja sistem.

2. Process

Proses adalah penyelenggaraan kerja atau jawaban, datangnya aliran data atau kondisinya

3. Data Stores

Data Stores adalah penyimpanan data

4. Data Flow

Data Flow merepresentasikan sebuah input data kedalam sebuah proses atau output dari data (atau informasi) pada sebuah proses.(Swara, Kom, \& Pebriadi, 2016)

\section{e. Entity Realation Diagram ( ERD )}

Entity Relation Diagram adalah bagian yang menunjukkan hubungan relasi antara entity yang ada dalam sistem.

Hubungan yang terjadi dalam ERD antara lain adalah:

a. One To One $(1: 1)$

Yaitu suatu entity yang hanya mempunyai satu hubungan dengan entity lain dan begitu pula sebaliknya.

b. One To Many $(1: \mathrm{M} / \mathrm{M}: 1)$

Yaitu suatu entity yang mempunyai satu hubungan dengan entity lain sedangkan entity lain mempunyai banyak hubungan dengan entity tersebut.

c. Many To Many (M : M)

Yaitu suat entity yang mempunyai banyak hubungan dengan entity lain dan begitu pula sebaliknya.(Yuhendra \& Eko Yulianto, 2015)

\section{f. HIPO ( Hirarci Plus Input Proses and Output ) \\ HIPO telah dirancang dan dikembangkan} secara khusus untuk menggambarkan suatu struktur bertingkat guna memahami fungsifungsi dari modul-modul suatu sistem, dan HIPO juga dirancang untuk menggambarkan modul-modul yang harus diselesaikan oleh pemrogram. Disamping itu HIPO menyediakan penjelasan yang lengkap dari input yang akan digunakan, proses yang akan dilakukan serta output yang diinginkan.(Liza Yulianti1, 2012)

\section{g. Visual Basic 6.0}

Visual Basic adalah sebuah bahasa pemograman komputer dan juga sering disebut sebagai sarana (tool) umtuk menghasilkan program-program aplikasi berbasiskan Windows.(Sophian, 2014)

\section{h. Context Diagram}

Context Diagram merupakan data flow diagram yang menggambarkan garis besar oprasional sistem. Konteks diagram mengambarkan hubungan sistem dengan entitas-entitas di luar sistem. CD memperlihatkan sistem sebuah proses. Tujuannya adalah memberikan pandangan umum sistem. CD memperlihatkan sebuah proses yang berinteraksi dengan lingkungan luarnya. Ada pihak yang memberikan masukan dan pihak yang menerima keluaran sistem.(Iswandy, 2015) 
IN F ORM A I I A

Jurnal Informatika, Manajemen dan Komputer, Vol. 10 No. 1 , MEI 2018

eISSN : 2580-3042

pISSN : 1979-0694

\section{i. Sistem}

Suatu sistem adalah suatu jaringan kerja dari prosedur-prosedur yang berhubungan, berkumpul bersama-sama untuk melakukan suatu kegiatan atau untuk menyelesaikan suatu kegiatan atau untuk menyelesaikan suatu sasaran yang di tentukan.(Elisawati, 2017)

\section{METODOLOGI PENELITIAN}

a. Kerangka Kerja

Pembahasan dan penyelesaian penelitian ini dilakukan dengan mengikuti kerangka kerja berikut:

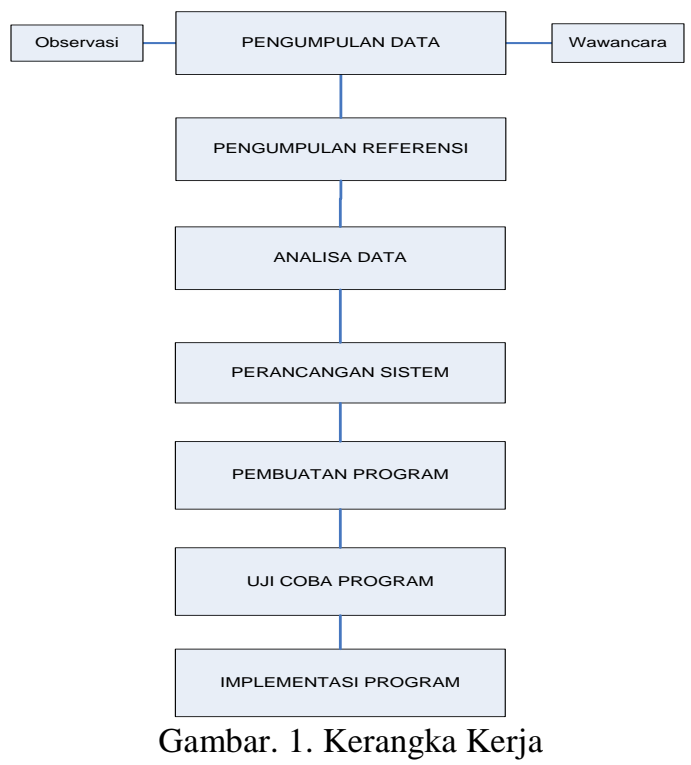

Berikut ini penjelasan mengenai gambar kerangka kerja di atas:

1. Mengumpulkan Data

Melakukan pengamatan langsung pada objek penelitian untuk mendapatkan data dan informasi yang benar dan akurat dengan melakukan:

a. Observasi

Yaitu dengan melakukan kunjungan langsung di toko Redha Dumai untuk mendapatkan data-data yang diperlukan serta mempelajari langsung kasus yang terjadi di lapangan.

b. Wawancara

Yaitu dengan melakukan wawancara dengan pemilik dan pihak-pihak yang terkait dengan permasalahan yang dibahas dalam penelitian ini. 2. Mengumpulkan referensi

Yaitu penelitian yang dilakukan untuk mendapatkan sumber referensi, yang berhubungan dengan buku-buku mengenai komputer, bahasa pemrograman, metode penelitian, database maupun buku umum lainya yang berhubungan dengan penelitian untuk pembuatan program aplikasi.

3. Analisa Data

Analisa data pada penelitian ini menggunakan metode deskriptif, dimana pada metode ini data yang ada dikumpulkan, disusun, di kelompokkan dan dianalisa sehingga diperoleh beberapa gambaran yang jelas pada permasalahan yang dibahas pada toko Redha Dumai.

4. Perancangan Sistem

Pada tahap ini dilakukan proses desain system dimulai dengan penyajian basis data, perancangan aliran system informasi, DFD, context diagram, ERD, desain input, desain output, dan perancangan file.

5. Pembuatan Program

Sistem informasi dibangun dengan menggunakan bahasa pemrograman VB 6.0 dengan Database MySQLyog berdasarkan perancangan sistem yang telah di rancang.

6. UjiCoba Program

Uji coba program dilakukan dengan menginputkan beberapa record data untuk memastikan bahwa program yang telah dirancang layak untuk di implementasikan.

7. Implementasi Program

a. Akses informasi dan pemesanan yang telah disajikan dari Aplikasi penjualan pada Toko bangunan Redha Dumai.

b. Melakukan proses transaksi pembelian melalui aplikasi penjualan pada toko bangunan Redha Dumai.

\section{HASIL DAN PEMBAHASAN}

a. AnalisisSistem

Analisis system merupakan kegiatan menguraikan suatu system informasi yang utuh dan nyata kedalam komponen yang bertujuan untuk mengidentifikasi serta mengevaluasi masalah-masalah yang muncul, sehingga mengarah kepada suatu solusi untuk perbaikan maupun pengembangan ke arah yang lebih baik dan sesuai dengan kebutuhan.

Penggunaan system informasi yang ada pada Toko Redha Dumai masih dilakukan dengan menggunakan tulisan tangan, oleh karena itu sulit untuk mencatat dan menghitung banyaknya jenis barang yang ada, maupun banyaknya jumlah barang. Banyaknya jumlah barang yang dijual dan tingkat keramaian pembeli dapat mengakibatkan penjual mengalami kesulitan untuk mengelola dan 
INFORM T IKA

Jurnal Informatika, Manajemen dan Komputer, Vol. 10 No. 1 , MEI 2018

eISSN : 2580-3042

pISSN : 1979-0694

menghitung transaksi penjualan secara cepat dan tepat. Untuk alur data sistem yang sedang berjalan di Toko Bangunan Redha Dumai akan diuraikan menggunakan Aliran Sistem Informasi.

Tabel 1. Aliran Sistem Informasi

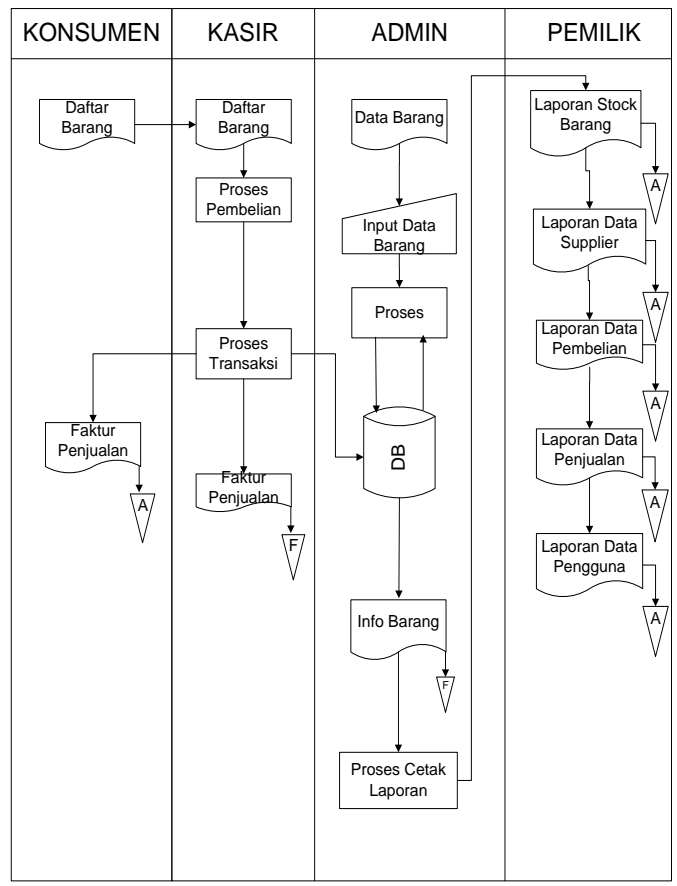

\section{b. Analisis Kebutuhan Sistem}

Perancangan aplikasi system Penjualan merupakan aplikasi yang digunakan untuk mengelola data pembelian dan penjualan di Toko Redha Dumai. Data pembelian dan penjualan ini meliputi pengelolaan input, proses, dan Output. Input berupa data barang, data supplier, data konsumen dan system juga harus dapat melakukan proses transaksi pembelian dan penjualan. Output yang diharapkan adalah memberikan informasi kepada pengguna yaitu laporan data barang, supplie, konsumen, laporan pembelian barang perhari, perbulan, dan pertahun serta laporan penjualan barang perhari, perbulan dan pertahun dan laporan pengguna.

\section{c. Pemodelan Proses}

1. Context Diagram

Berikut gambaran garis besar oprasional sistem pada apliksi pembelian dan penjualan di toko bangunan redha Dumai
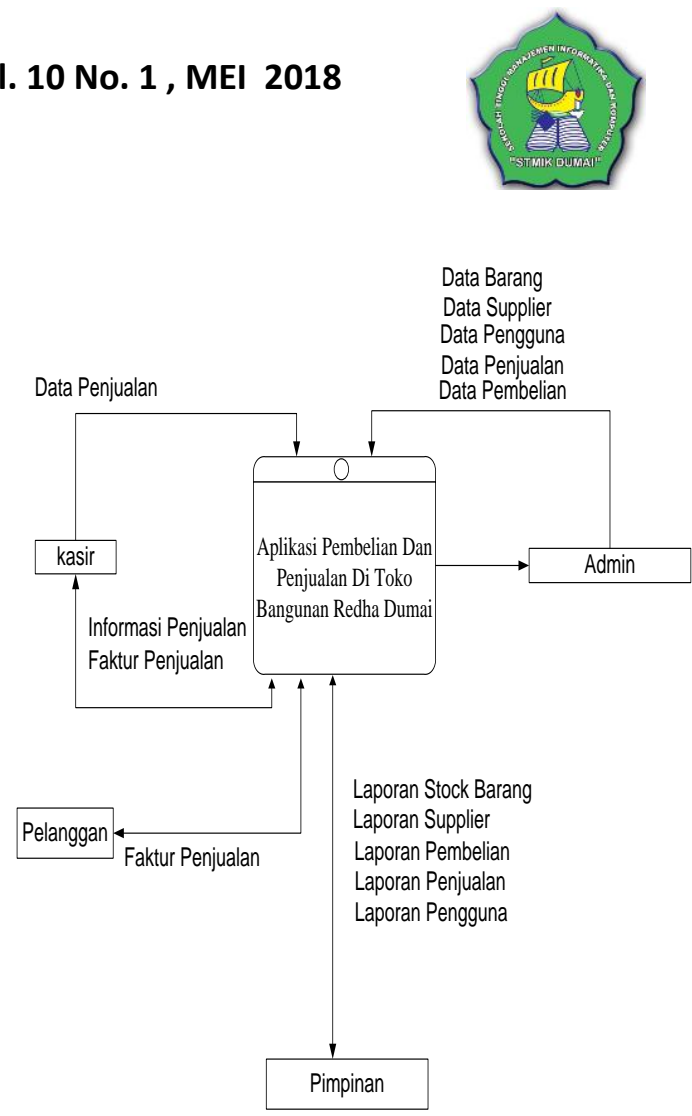

Gambar 2. Context Diagram

2. Data Flow Diagram

Berikut gambaran aliran data sampai sebuah sistem selesai pada aplikasi pembelian dan penjualan di toko bangunan redha Dumai

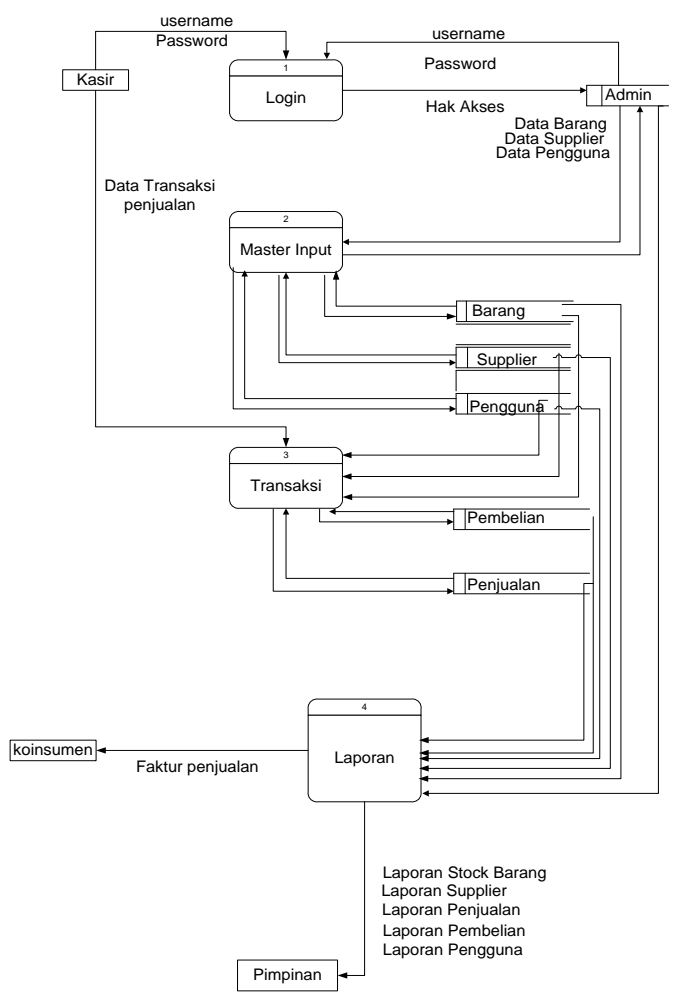

Gambar 3. Data Flow Diagram 
INFORM T IKA

Jurnal Informatika, Manajemen dan Komputer, Vol. 10 No. 1 , MEI 2018

eISSN : 2580-3042

pISSN : 1979-0694

3. Entity Relationship Diagram (ERD)

Menggambarkan database yang dibangun dengan model relasi.

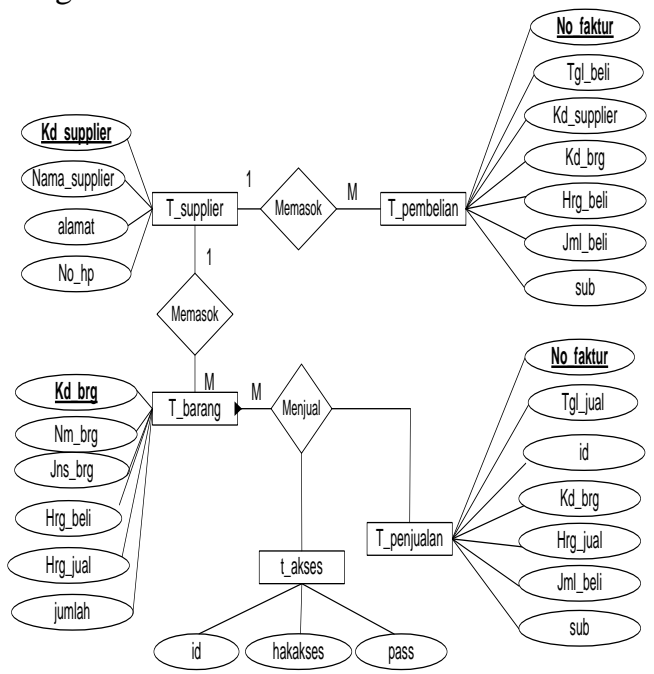

Gambar 4. ERD

4. Struktur Program (HIPO)

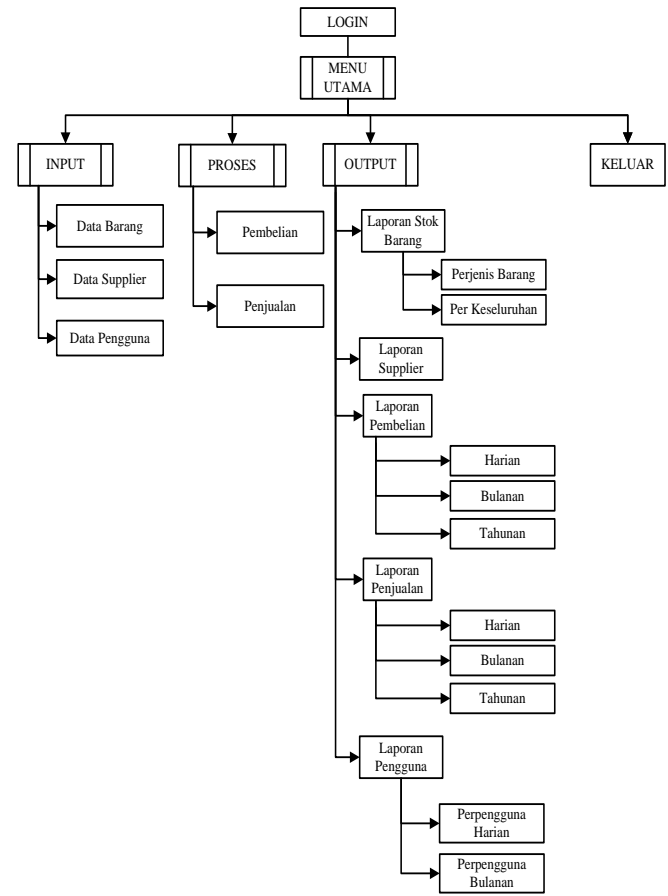

Gambar 5. Struktur Program (HIPO)
5. Pemodelan Logika dan Algoritma (FlowChart)

a. Flowchart Login

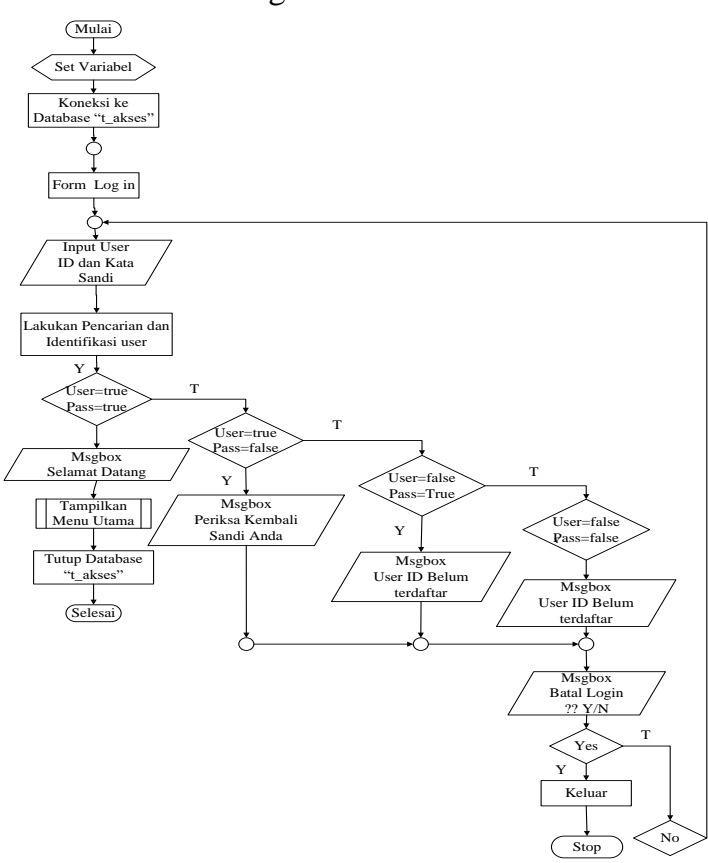

Gambar 6. Flowchart Login

b. Flowchart Menu Utama

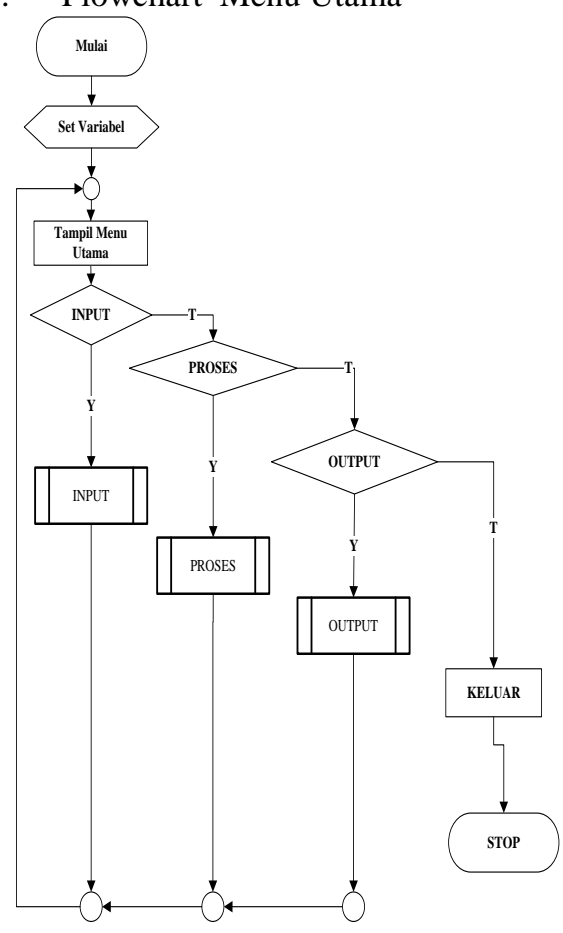

Gambar 7. Flowchart Menu Utama 
INFORM T IKA

Jurnal Informatika, Manajemen dan Komputer, Vol. 10 No. 1 , MEI 2018

eISSN : 2580-3042

pISSN : 1979-0694

c. Flowchart Input Data Supplier

e. Flowchart Input Data Pembelian Barang

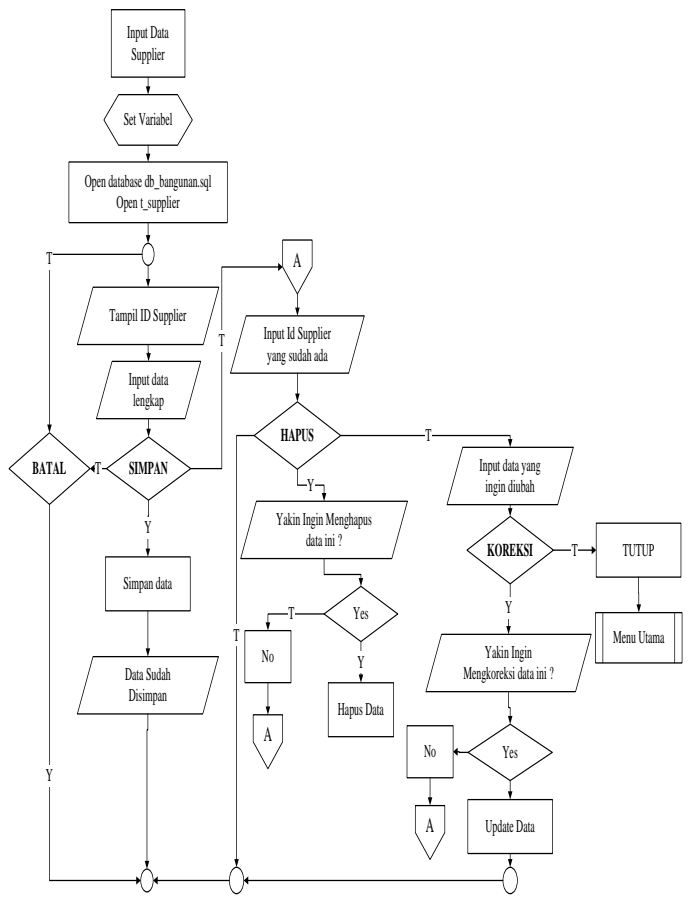

Gambar 8. Flowchart Input Data Supplier

d. Flowchart Input Data Barang

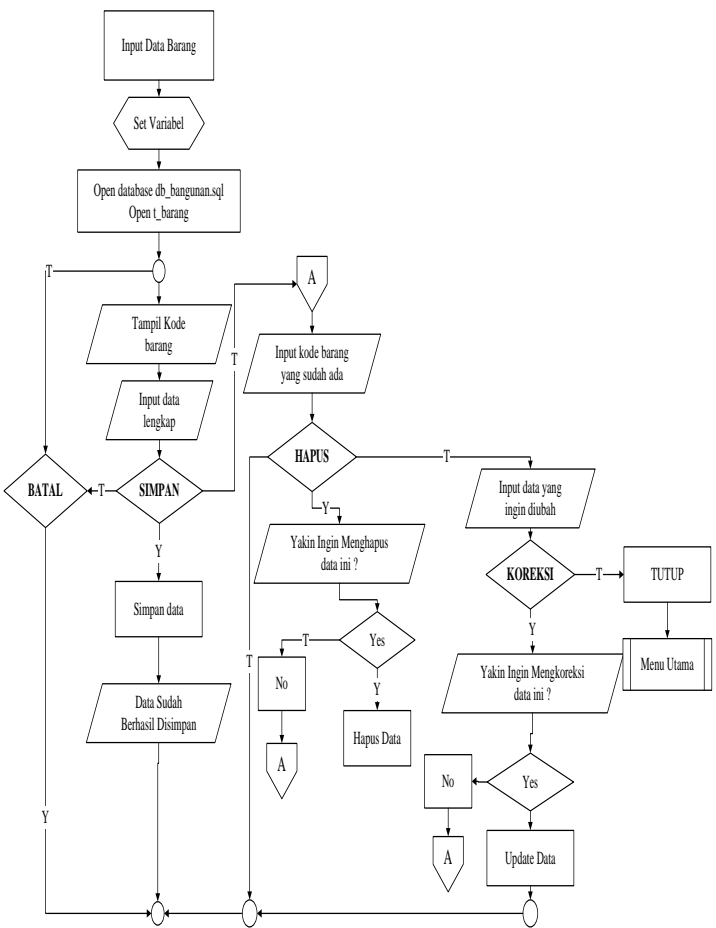

Gambar 9. Flowchart Input Data Barang

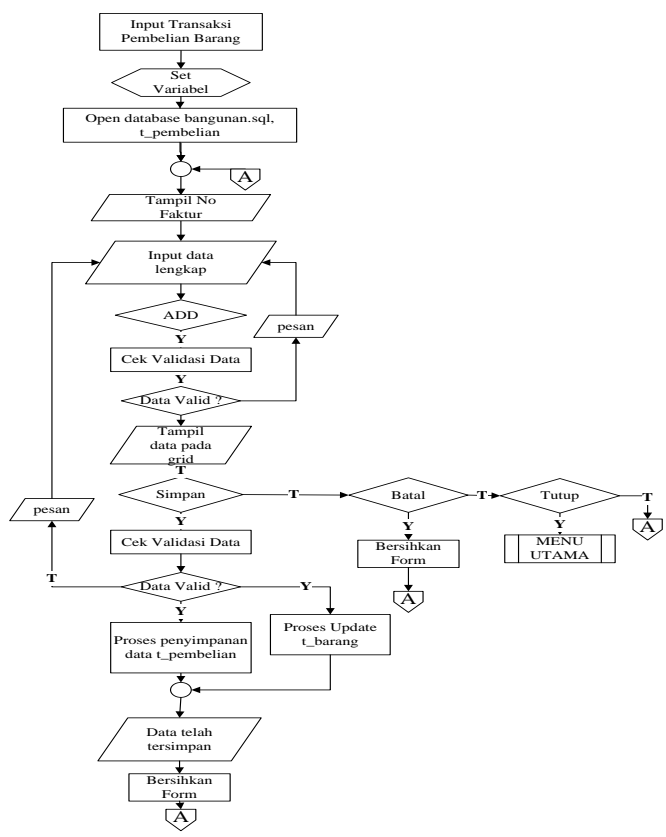

Gambar 10. Flowchart Input Data Pembelian Barang

f. Flowchart Input Data Penjualan Barang

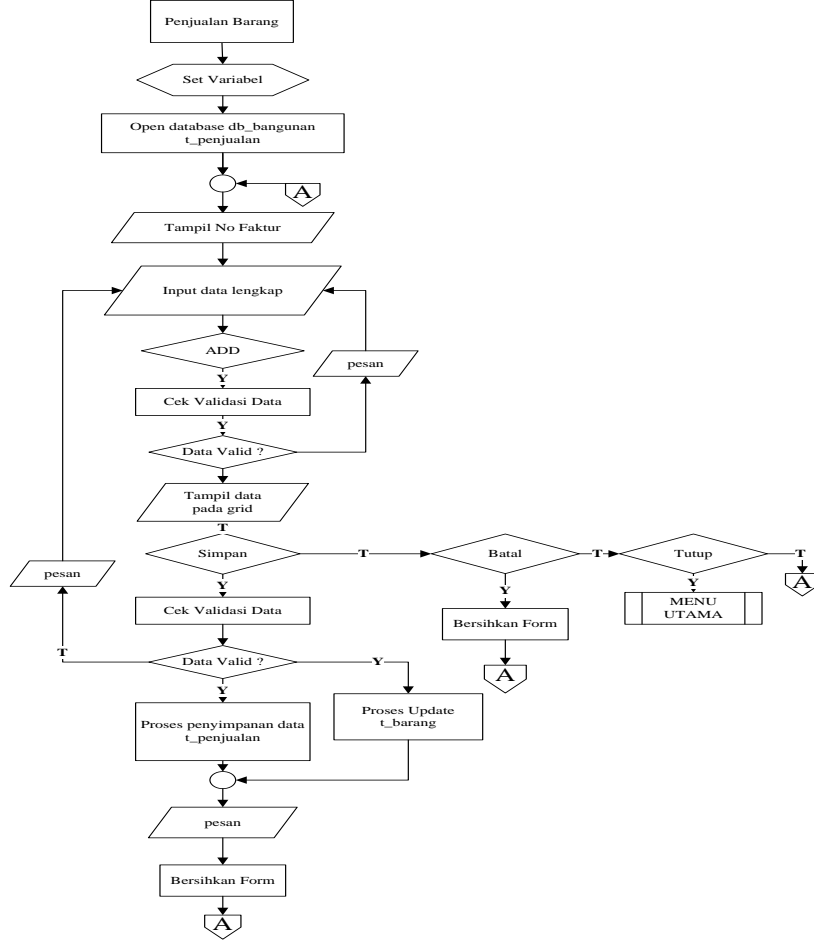

Gambar 11. Flowchart Input Data Penjualan Barang 
IN F O RM A I K A

Jurnal Informatika, Manajemen dan Komputer, Vol. 10 No. 1 , MEI 2018

eISSN : 2580-3042

pISSN : 1979-0694

\section{d. ImplementasiSistem}

1. Login Aplikasi

Jika koneksi sukses atau terhubung ke server maka akan muncul form login aplikasi. Masukkan nama pengguna dan password. Jika telah diisi dengan benar, maka program aplikasi utama terbuka.

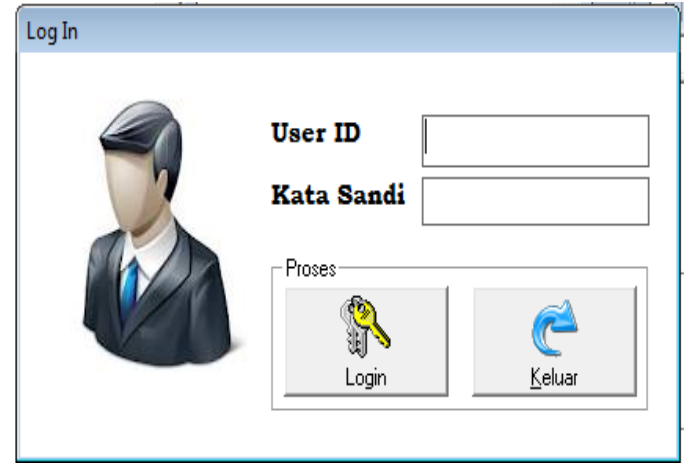

Gambar 12. Login Aplikasi

\section{Form Transaksi Pembelian}

Pada form ini digunakan untuk melakukan penginputan Barang yang akan dibeli ke supplier ada pun cara penginputannya adalah sebagai berikut:

1. Pada menu Proses klik submenu Pembelian dan akan tampil form sebagai berikut:

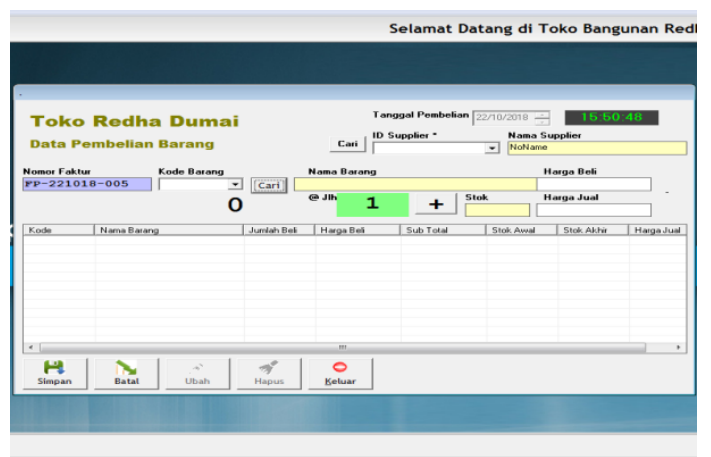

Gambar 13. Form Transaksi Pembelian

2. Kemudian silahkan input data pada setiap objek yang ada di form kemudian klik tombo ISIMPAN

3. Untuk membatalkan penginputan data silahkan klik tombol BATAL

4. Untuk mengubah pengimputan data silahkan klik tombol UBAH

5. Untuk menghapus penginputan data silahkan klik tombol HAPUS

6. Untuk keluar dari form ini klik tombol KELUAR
3. Form Transaksi Penjualan

Pada form ini digunakan untuk menginput data pembayaran. Ada pun cara penginputannya adalah sebagai berikut:

1. Pada menu Transaksi klik submenu Penjualan dan akan tampil form sebagai berikut:

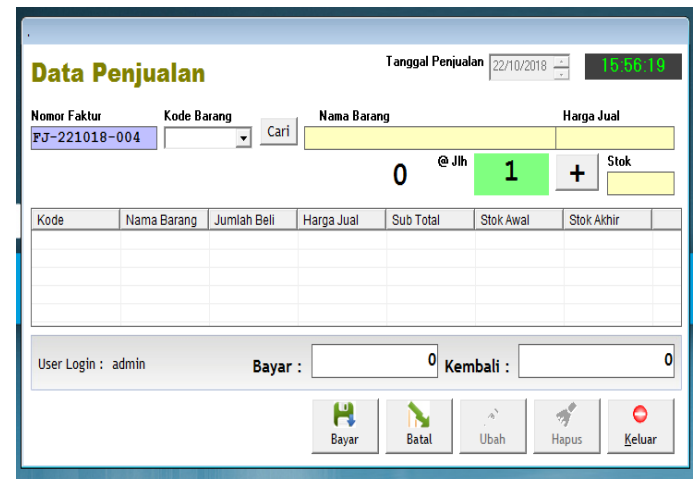

Gambar 14. Form Transaksi Penjualan

2. Kemudian silahkan input data pada setiap objek yang ada di form kemudian klik tombol BAYAR

3. Untuk membatalkan penginputan data silahkan klik tombol BATAL

4. Untuk mengubah penginputan data silahkan klik tombol UBAH

5. Untuk menghapus penginputan data silahkan klik tombol HAPUS

6. Untuk keluar dari form ini klik tombol KELUAR.

\section{KESIMPULAN}

Berdasarkan penelitian yang telah dilakukan dengan mengamati dan menganalisa sistem pengolahan data yang digunakan serta dilandasi oleh teori-teori dan alat-alat yang digunakan berkaitan dengan penelitian. Maka dapat disimpulkan bahwa untuk menerapkan sistem komputer dengan menggunakan suatu paket aplikasi komputer. Yang mana nantinya dapat menggantikan sistem lama yang ditangani secara manual. Maka berdasarkan uraian-uraian di atas, maka dapat diambil beberapa kesimpulan :

1. Dengan menggunakan sistem yang telah terkomputerisasi maka, dapat mempermudah dalam pembuatan laporan yang dibutuhkan.

2. Mengolah data dan penyimpanan data, dapat dilakukan secara cepat, tepat dan akurat karena menggunakan sistem database yang terstruktur dan terpusat. 
IN F O RM A I K A

Jurnal Informatika, Manajemen dan Komputer, Vol. 10 No. 1 , MEI 2018

eISSN : 2580-3042

pISSN : 1979-0694

3. Tingkat keamanan data lebih terjamin dengan adanya penggunaan password pada saat login.

\section{REFERENSI}

Elisawati. (2017). Sistem Deteksi Objek Dengan Menggunakan Sensor Ultrasonik Berbasis Fuzzy. Jurnal Informatika, Manajemen Dan Komputer, 9(1), 10-14.

Ismael. (2017). Jurnal EdikInformatika Semen Padang Untuk Daerah Bengkulu Selatan Di Jurnal Edikinformatika. Jurnal Edikinformatika, 2(2), 147-156.

Iswandy, E. (2015). Sistem Penunjang Keputusan Untuk Menentukan Penerimaan Mahasiswa Dan Pelajar Kurang Mampu, 3(2).

Kusbianto, D. (2010). Analisis Dan Perancangan Sistem Informasi. (Bangil, Pp. 1-140).

Liza Yulianti1, Y. (2012). Sistem Informasi Persediaan Barang Pada Pt . Surya Nusa Bhaktindo Bengkulu Abstract One Effort To Present Information About The Construction Material Supply House, Is One Of Them By Making Materials Inventory Application Using Microsoft Visual Basic 6 ., 8(1), 90-117.

Siswanto, Natalia, L., \& Aspriyono, H. (2012). Sistem Informasi Kantor Camat Ratu Samban Kota Bengkulu Berbasis Web. Jurnal Media Infortama, 8(2), 113-131.

Sophian, S. (2014). Pengimplementasikan Dan Perancangan Sistem Informasi Penjualan Dan Pengendalian Stok Barang Pada Toko Swastika Servis (Ss) Bangunan Dengan Menggunakan Bahasa Pemogaman Visual Basic 6.0 Didukung Dengan Database Mysql. Jurnal Momentum, 16(2), 34-44.

Suprayitno, U. I. W. (2012). Pembangunan Sistem Stok Barang Dan Penjualan Pada Toko Sero Elektronik. Indonesian Jurnal On Computer Science, 9(3), 94-103.

Swara, G. Y., Kom, M., \& Pebriadi, Y. (2016). Jurnal Teknoif Issn : 2338-2724 Rekayasa Perangkat Lunak Pemesanan Tiket

Bioskop Jurnal Teknoif Issn : 2338-2724. Jurnal Teknoif, 4(2), 27-39.

Yuhendra, D. E., \& Eko Yulianto, R. (2015). Rekayasa Perangkat Lunak Pengolahan Data Distribusi Obat- Obatan Di Pt. Anugrah Pharmindo Lestari Berbasis Web. Jurnal Momentum, 17(Agustus), 8.

Yunita, P. (2018). Aplikasi Perhitungan Payroll Dosen Pada Stmik Dumai. Jurnal Informatika, Manajemen Dan Komputer, 10(1), 18-21. 